\title{
Hypertrophic Neuropathy with Diabetes Mellitus
}

\author{
Satoru SHIRAISHI', Tasuku MiYOSHI', Naohide INOUE' and Yoshiyuki MUraI' \\ 'Department of Neurology, School of Medicine, University of Occupational and Environmental \\ Health, Japan. Kitakyushu 807, Japan \\ 2Department of Neurology, Kyushu Rosai Hospital. Kitakyushu 800-02, Japan
}

Abstract: A 52-year-old male with diabetes mellitus showed sensorimotor disturbance of symmetrical glove and stocking distribution. Electromyography demonstrated signs of denervation, and motor nerve conduction velocities could not be obtained because the muscle action potential was not evoked by the electrical stimulation of the nerves. Quantitative histologic and ultrastructual studies were performed in the sural nerve biopsy. Determinations of fiber densities revealed a striking decrease of both myelinated and unmyelinated fibers and remarkable increase of the onion bulb formations. Hypertrophic changes with onion bulb formations have been observed in various clinical conditions, particularly in hereditary disorders, but uncommon in diabetic neuropathy. Our case was non-familial and may form one atypical type of diabetic neuropathy.

Key words: hypertrophic neuropathy, onion bulb formation, diabetes mellitus.

(Received 15 February 1983)

\section{Introduction}

Diabetes mellitus is one of the most frequent causes of neuropathies. However, there have been only a few reports on the hypertrophic changes in diabetes mellitus neuropathy, and few studies have been made using modern histological techniques. The purpose of this paper is to describe the type of the involvement of the sural nerve biopsy in a diabetic patient applying modern histological techniques, and to present a case of atypical diabetic neuropathy.

\section{Report of a Case}

A 52-year-old male was admitted to Kyushu Rosai Hospital on June 19th, 1982. He was healthy before 1963 when he began to feel thirsty and was diagnosed as diabetes mellitus for the first time. He had not been treated properly for the diabetes mellitus until 1966, when he noticed muscle weakness and atrophy in the distal portion of the four extremities, which progressed gradually, but there was no sensory symptoms. He became unable to walk without a stick, and recognized mild numbness in the four extremities in 1975. He also noticed impotence at that time.

No similar symptoms were found in the other members of the family, and there was 
no consanguinity in his family. There was no history of exposure to any toxic chemical compound nor medicine, which was known to cause neuropathy.

On admission, a general physical examination showed moderate emaciation, mild high blood pressure and moderate diabetic retinopathy. Neurological examination revealed marked symmetrical atrophy and weakness in the distal part of the four extremities. Deep tendon reflexes were all absent. Sensory disturbance of all modalities was present in the distribution of glove and stocking, and he suffered from impotence, but there was no sphincter disturbance.

\section{Laboratory Data}

Blood chemistry showed no abnormal findings regarding liver and renal functions. The blood glucose level showed a diabetic pattern by the $50 \mathrm{~g}$ glucose tolerance test (pre.: 150, 1 hour: 322, 2 hours: $346 \mathrm{mg} / 100 \mathrm{ml}$ ). Urinalysis showed no protein but $18.3 \mathrm{~g}$ sugar/day. The cerebrospinal fluid contained $73 \mathrm{mg} / 100 \mathrm{ml}$ of protein without excess of cells, and serological studies for syphilis were negative in both blood and C. S. F. Vitamin $\mathrm{B}_{1}, \mathrm{~B}_{12}$, nicotinic acid were also normal.

Electromyography demonstrated abundant fibrillation potentials in the bilateral biceps and quadriceps muscles, and the number of motor unit potentials activated by voluntary contraction was makedly reduced in the muscles of the four extremiteis. On the motor conduction study, no evoked muscle action potential was obtained by the electrical stimulation of the median, ulnar and peroneal nerves. The sensory potential was not elicited in the median, ulnar and sural nerves.

\section{Clinical Course}

By the administration of $7.5 \mathrm{~g}$ glibenclamide per day and diet therapy the fasting blood sugar and daily excretion of urine sugar decreased. In spite of good control of the diabetes mellitus, sensory and motor disturbances had not improved in 5 weeks after the commencement of the treatment.

\section{Histological Studies}

The sural nerve biopsied at the ankle was fixed with $3 \%$ glutaraldehyde in a $0.1 \mathrm{M}$ cacodylate buffer ( $\mathrm{pH}$ 7.40) for 2 hours. Then the tissue was washed, and divided into two portions, one for epoxy sections and the other for teased fiber preparations. The former was postfixed in $2 \%$ osmium tetroxide for 2 hours, dehydrated, and embedded into epoxy. Thick epoxy sections with a thickness of $1.5 \mu \mathrm{m}$ were stained with toluidine blue, and observed using a light microscopy. Ultrathin sections were stained with ura- 


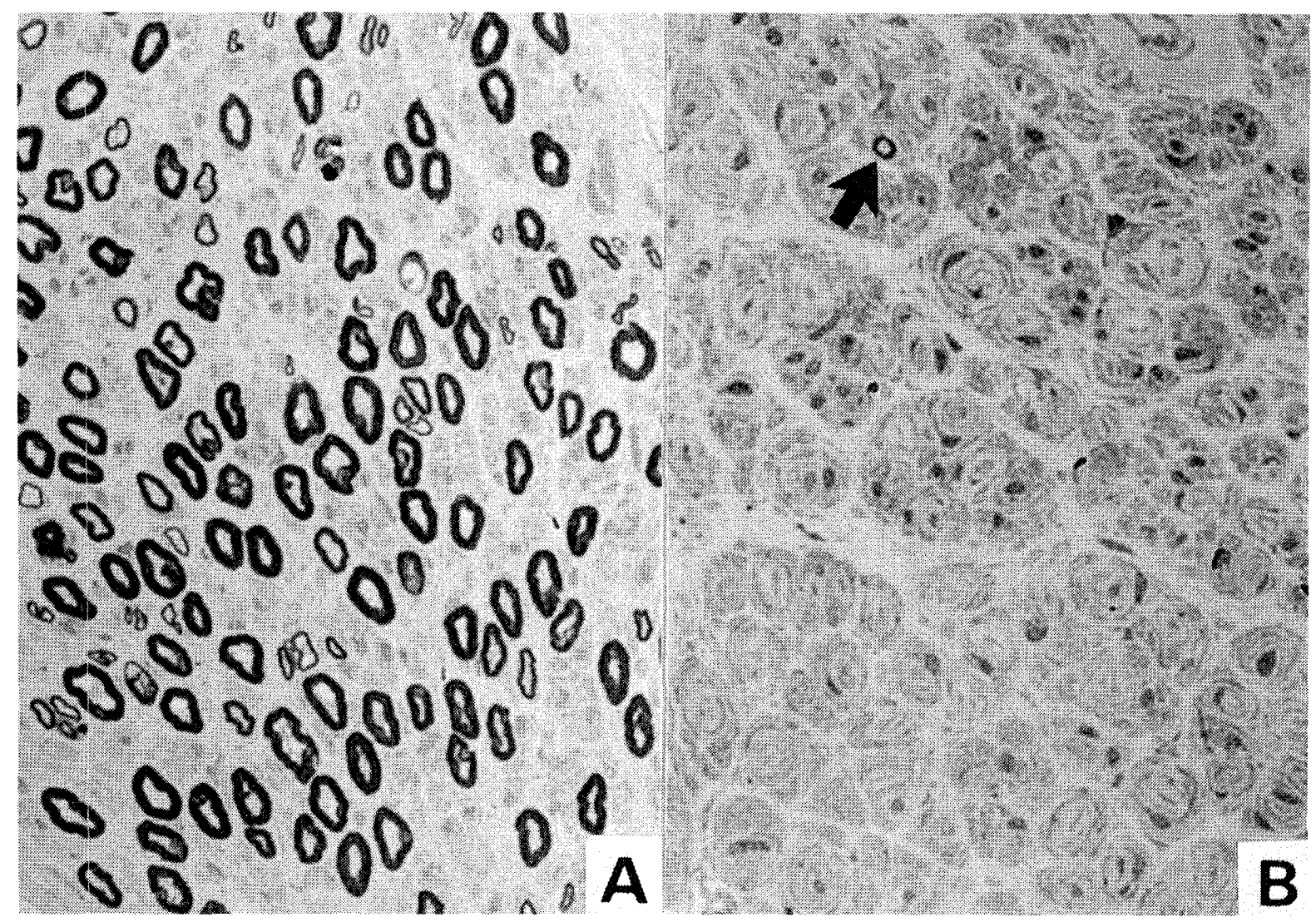

Fig. 1. Transverse section of sural nerve from control (A) and our case (B). Note multiple laminations of Schwann cell in the many onion bulb formations. Most of the onion bulbs lack a visible myelinated fibers and there was only one myelinated fiber obviously $(\overrightarrow{)}$ ). Toluidine blue staining $(\times 400)$.

Table 1. Number (No. $/ \mathrm{mm}^{2}$ ) of nerve fibers

\begin{tabular}{crrrr} 
& \multicolumn{3}{c}{ Myelinated fibers } & Unmyelinated \\
\cline { 2 - 4 } Sural nerve & Total & Large & Small & fibers \\
\hline Control & 8340 & 4149 & 4191 & 24420 \\
Patient & 280 & 0 & 280 & 5142 \\
\hline
\end{tabular}

Large fibers: Diameter $>5 \mu \mathrm{m}$, Small fibers: Diameter $\leqq 5 \mu \mathrm{m}$

nyl acetate and lead citrate, and examined with an electron microscope for the purpose of condition analysis of each fiber. Photographic enlargements $(\times 1,000)$ of the transverse epoxy sections were used to obtain the density (the number per square millimeter of fascicular area) of large (diameter $>5 \mu \mathrm{m}$ ) and small (diameter $\leqq 5 \mu \mathrm{m}$ ) and total (both large and small) myelinated fibers and their size frequency distribution. In order to obtain the density and size frequency distribution of unmyelinated fibers, electron micrographs $(\times 7,500)$ were used. 

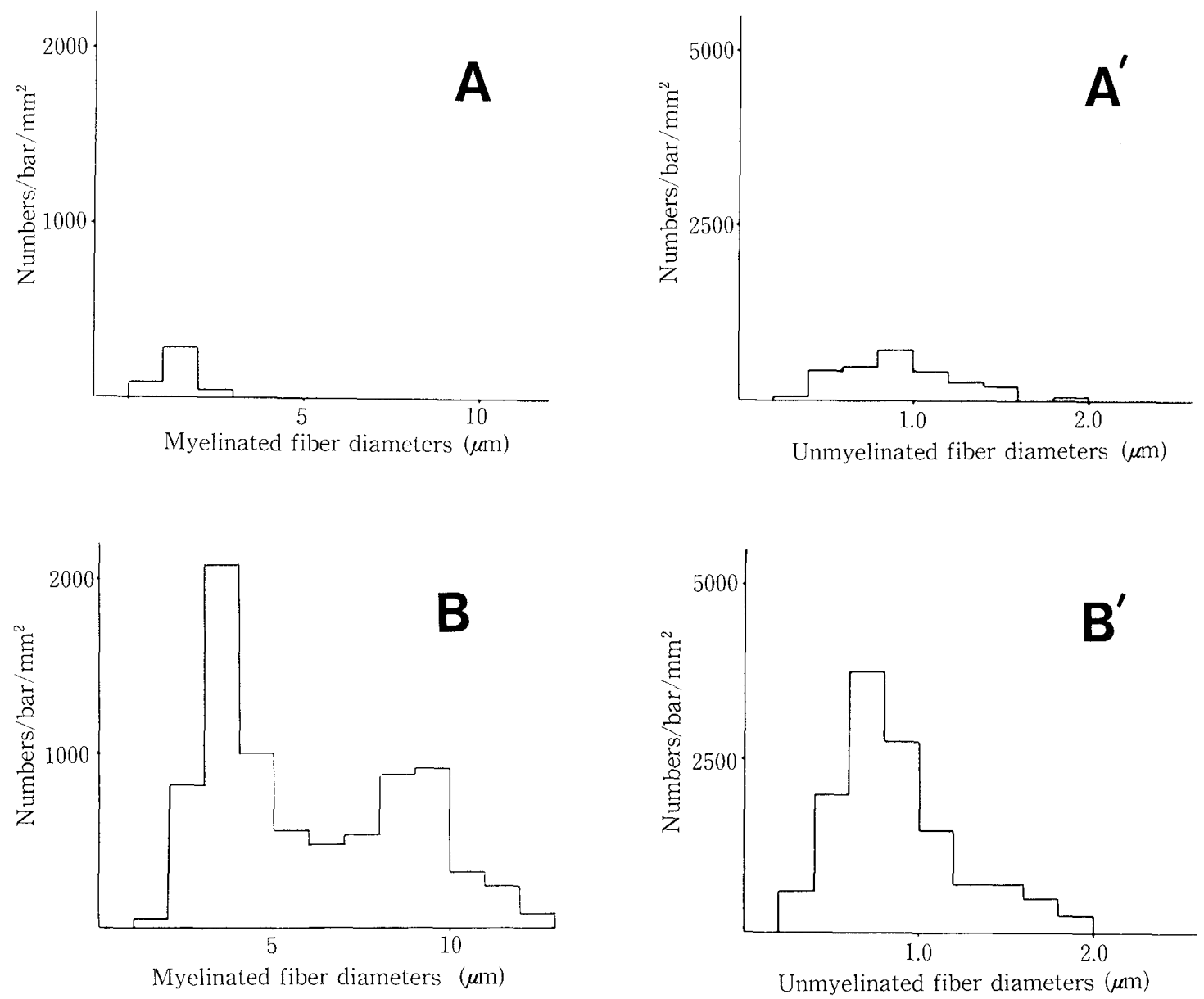

Fig. 2. The diameter histograms of myelinated and unmyelinated fibers per square millimeter of fascicular area of sural nerve in control (lower $B, B^{\prime}$ ) and this patient (upper $A, A^{\prime}$ ). Note remarkable decrease in number of myelinated $(A)$ and unmyelinated fibers $\left(A^{\prime}\right)$.

\section{Light Microscopy}

The transverse epoxy section viewed under a light microscopy frequently showed multiple laminations of Schwann cells in the onion bulb formations. Most of the onion bulbs lacked a visible myelinated fiber (Fig. 1). The density of total, large and small myelinated fibers is shown in Table 1 and Fig. 2. The density of large myelinated fibers completely disappeared and small myelinated fibers showed a remarkable decrease. The condition of each teased fiber could not be classified because of a too marked reduction of myelinated fibers.

\section{Electron Microscopy}

Electron microscopic findings also showed onion bulb formation. The central zone was surrounded by Schwann cell cytoplasmic processes and fibroblast, and there were 




Fig. 3-A. Electron micrograph (E. M.) of the sural nerve in transverse section. The central zone was surrounded by Schwann cell cytoplasmic processes. Two Schwann cell nuclei were visible. $(\times 10,000)$.

more collagens in the interstices between Schwann cell processes (Fig. 3). The unmyelinated fiber density showed remarkable decrease (Table 1 and Fig. 2).

\section{Discussion}

The patient presented here was a middle-aged male with diabetes mellitus who developed slowly progressive sensorimotor neuropathy in the four extremities. Histological study of the sural nerve showed remarkable loss of myelinated and unmyelinated fibers and onion bulb formations. Since the case presented here did not have any hereditary factor nor condition, which could damage peripheral neves except for diabetes mellitus, diabetes mellitus was attributed to this hypertrophic neuropathy.

Thomas \& Eliasson (1975) classified diabetic neuropathy into two clinical categories, 


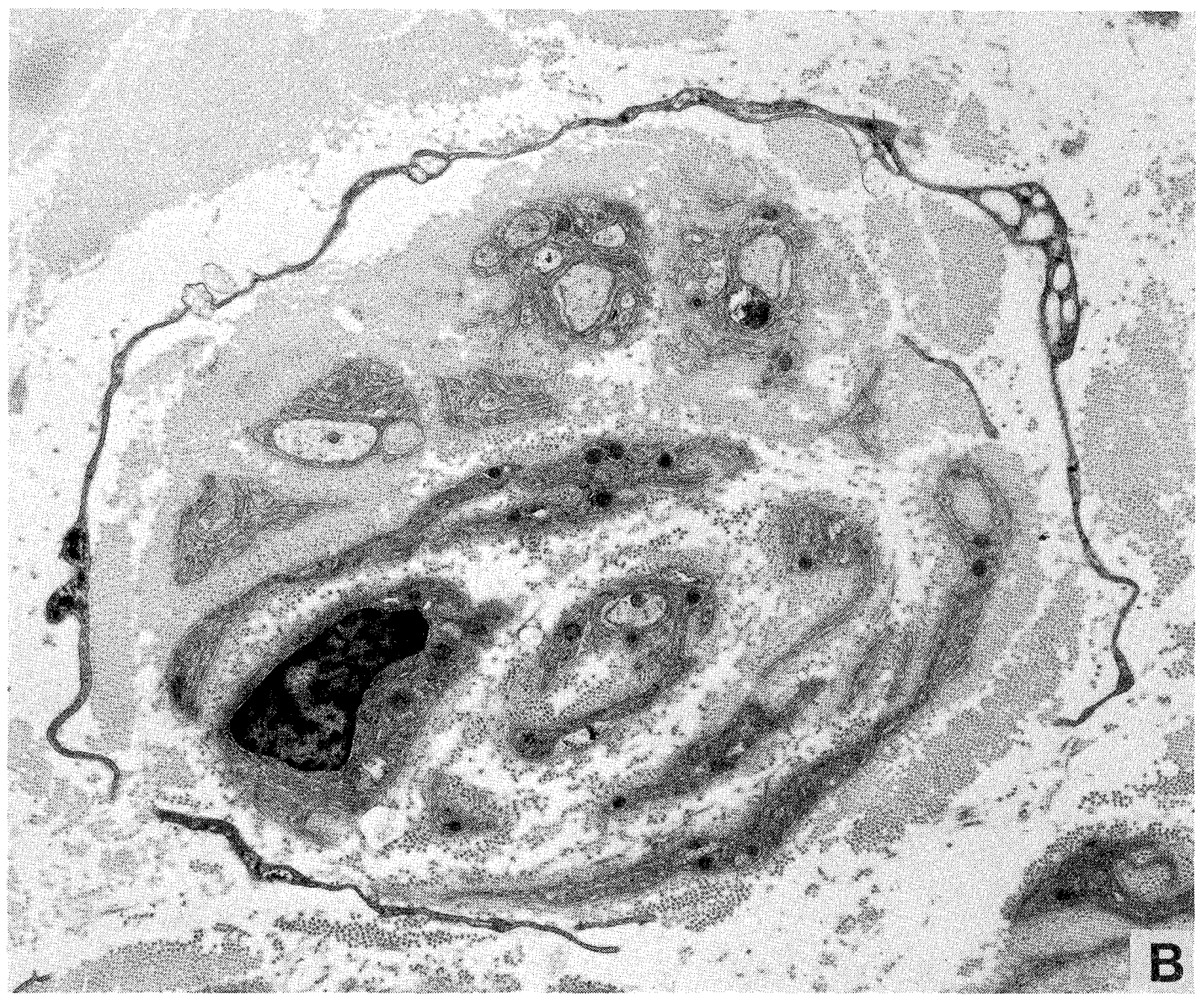

Fig. 3-B. E. M. section of an onion bulb formation. This onion bulb had collagen in the interstices between Schwann cell process and surrounding fibroblast process. $(\times 10,000)$.

(I) symmetrical polyneuropathy, which shows symmetrical involvement of peripheral nerves and (II) mononeuropathy and multiple mononeuropathy. Symmetrical polyneuropathy was usually sensory and autonomic predominant.

The major pathological change of diabetic neuropathy is loss of axons and more prominent involvement in the distal nerves (Thomas \& Lascelles, 1966; Olsson et al., 1968). Also no specific quantitative changes in axon or Schwann cells have been recognized to serve to distinguish diabetic polyneuropathy from chronic axonal neuropathies of other causes (Brown et al., 1976). Concerning hypertrophic changes in diabetic neuropathy, a few cases have been reported. Greenbaum et al. (1964), Tomas \& Lascelles (1966), Ballin \& Thomas (1968), Chaussé et al. (1973) described hypertrophic neuropathy in the cases of diabetes melitus. All of these cases showed mononeuritis or mononeuritis multiplex, and were never symmetric. However, Antoku et al. (1979) reported a 58-yearold female, who suffered from poorly controlled diabetes mellitus for 11 years and de- 
veloped symmetrical sensorimotor disturbance with glove and stocking type. Neither a similar disease nor consanguinity was found in her family, and the sural nerve biopsied showed loss of myelinated fibers with onion bulb formation.

Antoku's case was similar to ours clinically and histologically, and they may form an atypical type of diabetic neuropathy.

\section{References}

Antoku, Y., Iwashita, H., Goto, I. et al. (1979): Hypertrophic sensorimotor polyneuropathy in diabetes in diabetes mellitus. Report of a case. Clin. Neurol., 10: 65-69.

Ballin, R. H. M. \& Thomas, P. K. (1968): Hypertrophic changes in diabetic neuropathy. Acta Neuropathol., 11: 93-102.

Brown, M. J., Martin, J. R. \& Asbury, A. K. (1976): Painful diabetic neuropathy: A morphometric study. Arch. Neurol., 33: 164-171.

Chaussé, J. D., Vital, U., Dehais, J. et al. (1973): La prolifération schwannienne de la neuropathie diabétique. Nouv. Presse Méd., 24: 2801-2804.

Greenbaum, D., Richardson, P. C., Salmon, M. V. et al. (1964): Pathological observations on six cases of diabetic neuropathy. Brain, 87: 201-214.

Olsson, Y., Säve-Söderbergh, J., Sourander, P. et al. (1968): A pathoanatomical study of the central and peripheral nerves system in diabetes and early onset and long duration. Pathol. Eur., 3: 62-79.

Thomas, P. K. \& Eliasson, S. G. (1975): Diabetic neuropathy. In: Peripheral Neuropathy. (Dyck, P. J., Thomas, P. K. \& Lambert, E. H., ed.). W. B. Saunders, Philadelphia. pp. 956-981.

Thomas, P. K. \& Lascelles, S. G. (1966): The pathology of diabetic neuropathy. Q. J. Med., 35: 489509.

糖尿病に伴う肥厚性ニューロパシー

白石悟 1 三好 甫 ${ }^{2}$ 井上 尚英 ${ }^{1}$ 村井 由之'

産業医科大学神経内科学教室 2九州労災病院神経内科

要旨：症例は 52 歲, 男性, 19 年間の糖尿病歴があり, 手袋靴下状に左右対称性の運動感覚障害 を呈した，筋電図では脱神経所見を呈し，末梢神経伝導検查では運動感覚神経共に誘発不 能であった，腓腹神経による組織定量的な解析と電子顕微鏡的観察では有髄線維，無髄線 維共にコントロールに比べて著名な線維密度の減少および onion bulb 形成の明らかな增 加を認め, 肥厚性ニューロパシーの所見を呈した。現在まで糖尿病を伴う肥厚性二ューロ パシーの報告は数例あるが，1例を除いていずれも左在非対称であり，私共のように糖尿 病に伴う左右対称性の肥厚性二ューロパシーの例はきわめて稀であり, 組織定量的所見に ついて細述した。 